\title{
The Perils of Consensus: How ASEAN's Meta-Regime Undermines Economic and Environmental Cooperation
}

\author{
Vinod K. Aggarwal and Jonathan T. Chow \\ Berkeley APEC Study Center \\ 802 Barrows Hall, \#1970 \\ University of California \\ Berkeley, California 94720-1970 \\ Tel.: 510-643-1071 \\ Fax: 510-643-1746 \\ Email: vinod@berkeley.edu and jchow@berkeley.edu
}

July 2009

An earlier version of this article was presented at the International Studies Association meeting in San Francisco, California, March 27, 2008. Kristi Govella, Ross Cheriton, Vaishnavi Jayakumar, and Anne Meng provided valuable research assistance and comments. We would also like to thank the anonymous reviewers for their insightful suggestions. 


\section{INTRODUCTION}

Since its establishment in 1967, the Association of Southeast Asian Nations (ASEAN) has undergone a remarkable transformation. Originally conceived to address political and security issues on a regional basis, ASEAN's scope has evolved to include a broad range of economic, environmental and social issues, and its membership has grown to include all of the states in Southeast Asia. Yet ASEAN's efforts to foster deeper integration have met with significant challenges. Two notable examples are its attempts to establish an ASEAN Economic Community (AEC) to address competition for investment from China and India, and its efforts to reduce the perennial haze from large-scale forest fires. On both of these critical issues, ASEAN has elicited only limited cooperation from its member states, resulting in halting progress.

Some scholars point to ASEAN's institutional norms—-particularly the norm of noninterference—as a persistent obstacle to deeper regional cooperation (e.g. Acharya, 2001, 2003; Haacke, 2003a; Jones and Smith, 2007; Ramcharan, 2000). While we agree that the norm of noninterference hinders regional integration and that it is unlikely to disappear-especially in security matters—-we nevertheless argue that it may be possible to circumvent it in other issue areas by reconfiguring institutional arrangements. In this article, we present an institutional design model that demonstrates how shared norms — the foundation of international regimes— both give rise to and are shaped by regime structures and state-level decisions. We briefly describe how ASEAN's key norms developed in the context of Southeast Asia's security situation and then use our framework to analyze the evolution of the ASEAN Economic Community trade and the ASEAN anti-haze regime. In the conclusion, we consider how ASEAN might be able to strengthen both regimes while still protecting member states’ sovereignty. 


\section{AN ANATOMY OF GOVERNANCE STRUCTURES}

Understanding the development of international governance structures and how they shape interactions requires us to understand how their individual components fit together and influence the particular character of the arrangement (see Figure 1).

\section{[FIGURE 1 ABOUT HERE]}

To concretize the discussion, we use this model to dissect the key components of the GATT/WTO. Starting at the bottom of the schematic, interactions refer to the trade flows of goods and services in the global economy. Directly above interactions are national actions. These can include unilateral measures or ad hoc bilateral accords, such as tariffs or environmental controls. The externalities of these actions can give rise to demand for new governance structures. For example, the spillover effects of protectionism in the 1930s generated pressure for an international approach to manage individual national actions, leading to the creation of the GATT in 1947.

International regimes (the next level up in Figure 1) refer to sets of rules and procedures around which actors' expectations converge, while meta-regimes (the top level in Figure 1) consist of the principles and norms that guide the entire regime. These definitions differ from the classic formulation articulated by Krasner (1983). While Krasner defines regimes as 'sets of implicit and explicit principles, norms, rules and decision-making procedures around which actors' expectations converge', we follow Aggarwal's (1985) separation of principles and norms ('meta-regimes') and the concrete rules and procedures that instantiate them ('regimes'). The logic behind this differentiation of meta-regimes and regimes is two-fold. First, as we argue below and as Aggarwal (1985) and other scholars have noted (Haas 1980), the causal factors 
driving the creation of principles and norms — respectively defined by Krasner as 'beliefs of fact, causation and rectitude' and 'standards of behavior defined in terms of rights and obligations'are significantly different than those that drive rules and procedures (Krasner, 1982: 186). Second, different regimes may draw on a similar meta-regime. For example, the Multi-Fiber Arrangement and the GATT both drew on the meta-regime of trade liberalization, reciprocity, safeguard, and other norms (Finlayson and Zacher, 1981), albeit with some modifications (Aggarwal, 1985), just as the Asia Pacific Economic Cooperation (APEC) forum and the North American Free Trade Agreement (NAFTA) draw on GATT norms (Aggarwal 1994). Another example is how the underlying meta-regime of institutional monetary cooperation persisted after 1971 even though the regime changed from a fixed exchange rate one to a floating one after 1973.

More specifically, we can classify regimes in terms of their strength, nature, and scope (Aggarwal, 1985). Strength refers to the stringency and specificity of the regime’s multilateral rules and the degree to which such agreements are institutionalized. Nature can be understood as the general intent behind the regime. Scope consists of two parts: issue scope refers to the number of issues incorporated into the regime, while member scope refers to the number of actors who are parties to the regime. For example, the GATT regime was quite strong and specific in its rules and procedures, but the WTO has increased this specificity and created even more stringent enforcement mechanisms. With some exceptions, it has been liberal in nature, and both its issue and membership scopes have dramatically expanded over time. Significant changes in these elements would constitute regime evolution and change.

We can think more systematically about the causal factors influencing the creation of each of the four elements described above. Figure 2 illustrates these in diagrammatic form. 


\section{[FIGURE 2 HERE]}

Meta-regime demand is driven by policymakers who perceive the need for underlying norms and principles to address their own goals or to respond to pressures from interest groups. These norms and principles, in turn, grow out of policymakers' consensual knowledge. Such knowledge can originate from a variety of sources, such as existing institutions, scientific and technical experts, or the policymakers themselves. It is important to note that knowledge is not necessarily what experts tout or even what is objectively true but rather what is widely accepted. Haas writes, 'It is normal that technical specialists originate a particular body of knowledge and claim relevance for it. Knowledge becomes salient to regime construction only after it has seeped into the consciousness of policy makers and other influential groups and individuals.' (Haas, 1980: 369). Although powerful states may play a role in managing knowledge, or acting as advocates for particular sets of principles and norms, by separating meta-regimes from regimes in our analysis, we can focus on consensually accepted elements as distinct from the imposition of specific structures that manifest themselves in rules and procedures.

The creation and evolution of an international regime is a function of both the metaregime and a set of regime-specific supply and demand factors. Traditionally, regimes have been supplied by a hegemon (or a very small group of powerful states) with the capacity to coordinate international policies. Political actors generally demand regimes for three reasons. First, regimes reduce transaction costs, particularly the costs of providing information to participants and of negotiating and implementing individual accords (Keohane, 1984). Second, actors may wish to control the behavior of other international and domestic actors through rule-based systems rather than through direct coercion. In a domestic context, signing an international agreement may 
bolster politicians' ability to reject demands from interest groups. Finally, decision-makers may try to bring lower-level (i.e. more specific) arrangements into conformity with broader institutions. This ‘institutional nesting’ discourages actors from participating in arrangements that might undermine broader accords because of their more significant concerns with these higher-level institutions (Aggarwal 1985 and 1998).

If institutions relevant to the issue area already exist, the question of institutional fit becomes central. We can define four types of connections among institutions: (1) nested links; (2) horizontal links; (3) overlap; and (4) complete independence. With nested links, institutional arrangements are subsumed within broader accords. For example, the Multi-Fiber Arrangement was firmly embedded in the GATT and drew upon and modified its principles and norms to manage trade in textiles. Institutions can also be horizontally connected, providing a division of labor as with the IMF and World Bank, the former focusing on short-term balance of lending and the latter on longer-term development loans. Institutions can also overlap, which can generate problems of coordination and determining who has authority. Efforts to create an Asian Monetary Fund (AMF) after the Asian financial crisis reflect the debate over institutional conflict that could have arisen from overlapping mandates. Finally, institutions may be independent, without any functional overlap. An example of independent institutions would be the North Atlantic Treaty Organization (NATO) and APEC. While the U.S. is a member of both, these institutions have different institutional missions, and thus do not create any conflict.

Moving down the diagram, national actions refer to domestic-level factors that shape the extent to which a state abides by the rules of a regime. These include the dominant ideology motivating state decision-makers as well as the extent to which they are insulated from domestic interest group pressures. It is not hard to imagine that in order to satisfy domestic demands, some 
states may attempt to evade regime restrictions or 'free-ride', thus reaping the public goods benefits of liberal international accords without actually having to comply with them (or pay the domestic costs of complying with them).

Finally, at the level of interactions, changes in technology, organization, and tastes (among other significant factors) will also continue to influence the supply and demand for goods and services, frequently leading to the creation of new externalities, altered transaction costs, or new challenges to existing institutional structures. As indicated by the feedback loop in Figure 2, these interactions may once again drive changes in the basic causal factors that influence both governance structures and interactions.

Our key analytical interest lies in understanding how institutions evolve over time in response to problems with existing institutions, secular trends, and new shocks. ${ }^{1}$ In the following sections, we apply this framework to ASEAN and examine how national bargaining strategies have shaped the efforts to create new governance structures in trade and haze in response to changing trends and shocks. We begin by provide an overview of the meta-regime that circumscribes and conditions the arrangements established within ASEAN.

\section{THE SECURITY ORIGINS OF ASEAN'S META-REGIME ${ }^{2}$}

Since its inception in 1967, ASEAN has espoused a set of norms as a framework for interaction among its member states. These substantive and procedural norms (Finlayson and Zacher, 1981), enshrined within various ASEAN documents and exhibited in regular interactions, include the substantive norms of respect for sovereignty, non-interference in other member states’ domestic

\footnotetext{
${ }^{1}$ For a more detailed analysis of the dynamics of institutional change, see Aggarwal (1998).

${ }^{2}$ This section draws heavily on Chow (2003), pp. 14-23.
} 
affairs, and peaceful dispute settlement. The procedural norms include a preference for informal elite-based diplomacy, decision-making by mutual consultation and consensus, and a preference for incrementalism. Undergirding these norms is a basic belief that regional cooperation will provide member states with enhanced political and economic benefits, both in the region and in the region's dealings in the broader international system. Together, these norms and beliefs constitute the ASEAN meta-regime.

As we note in Figure 2, the development of a meta-regime depends upon a supply of consensual knowledge among policymakers and a demand for international institutions prompted by changing systemic conditions. On the supply side, the origin of the meta-regime can be partly located in the principles of the UN Charter as well as the reconciliatory missions of the ill-fated Association of Southeast Asia (ASA) and Maphilindo; but perhaps more importantly, they emerged out of elites' shared understanding of the importance of protecting state sovereignty, fighting communism, and preventing regional disputes from boiling over (Leifer, 1989: 24). On the demand side, political elites' common experiences in the Cold War and common threat perceptions following Indonesian President Sukarno’s Konfrontasi ('confrontation’) campaign from 1963-1965 were a primary impetus driving the creation of a meta-regime. Konfrontasi was designed to weaken the newly formed Malaysian Federation through military harassment and diplomatic offensives. It was driven in part by a vigorous nationalism that viewed the formation of the Malaysian Federation as imperialist meddling by the British. Crucially, Sukarno also faced a precarious domestic political situation with an economy undergoing stagflation and a political rivalry between the military and the Indonesian Communist Party (PKI) (Narine, 2002:10; Andaya and Andaya, 2001:286; Mackie, 1974: 89). Konfrontasi began to unravel with a failed coup attempt on October 1, 1965. In response, the conservative Indonesian army, led by Major 
General Suharto, used the opportunity to conduct a massive purge of actual and suspected communists, whom they blamed for the coup. With the PKI decimated, Suharto was able to seize the presidency from Sukarno in March 1966 and quickly began to overturn the latter's foreign policies, including renouncing Konfrontasi.

Konfrontasi demonstrated to the Southeast Asian states that domestic strife could have regional spillover effects and left them eager to avoid future interference in their domestic affairs, whether from within the region or without. In the 1967 Bangkok Declaration establishing ASEAN, the member states - then consisting of Indonesia, Malaysia, the Philippines, Singapore and Thailand—asserted that they would work together to enhance economic and security cooperation and set their own course as a region. Each of these states had its own reasons for agreeing to the ASEAN project. For Indonesia, joining ASEAN was an opportunity to rebuild trust within the region following Konfrontasi and take on a leadership role, though other states also regarded ASEAN as a way to channel Indonesia's regional ambitions down a non-violent path (Acharya, 2001:49). Malaysia, Singapore and Thailand saw ASEAN as a measure of insurance against intra-regional conflict following Great Britain’s 1967 announcement that it would withdraw from East of Suez by 1975 (later amended to 1971) and the United States’ 1969 Guam Doctrine repudiating its commitment to fight wars on continental Asia. Finally, the Philippines believed that its membership in an indigenous regional organization would enable it to share more fully in Asian political and economic interactions by helping to offset its relationship with the United States. During his opening speech to the Fourth ASEAN Ministerial Meeting in March 1971, Philippine Foreign Minister Carlos Romulo said that 'countries in the region had been helpless victims of world powers in their ideological power play' and that 'from this common misfortune grew an awakening to their common identity and community of 
interests.' (ASEAN, 1971). These ideas were enshrined in the 1971 Zone of Peace, Freedom and Neutrality Declaration and the 1976 Treaty of Amity and Cooperation, which together formed the cornerstone of ASEAN's norms of non-interference and respect for sovereignty. It is noteworthy that the formation of ASEAN did not require the lead of a hegemonic state but instead arose from shared threat perceptions among the different members that were born of the Cold War. In this sense, ASEAN resembled the $19^{\text {th }}$-century Concert of Europe, which lacked a single hegemonic pole but instead grew out of a shared realization of the dangers of an imbalance of power that, in turn, was born from the member states' common experience of the Napoleonic Wars.

ASEAN's organizational culture has exhibited a clear preference for informal diplomacy and personal elite relationships over rule-based interaction. This informal diplomacy has historically resulted in discussion, confidence-building measures, and non-binding declarations of intent rather than policies with the force or semblance of international law. Although these norms of interaction are consistent with ASEAN's aversion to any external constraints on their sovereign control, they have also generated criticisms that ASEAN is little more than a 'talk shop'. On the other hand, the informality of the 'ASEAN Way' has arguably made ASEAN's member states more willing to discuss certain sensitive topics that might not otherwise be open for discussion.

Informal diplomacy exists hand-in-hand with the key procedural norm of decisionmaking by mutual consultation and consensus. Discussion in ASEAN is conducted via a process whereby each party articulates its viewpoints before a final decision is made. Decisions are not voted upon but rather made based on consensus. In the event of a deadlock, member states typically revert to bilateral negotiations. Thus, ASEAN's collective decisions have tended to 
reflect the lowest common denominator of interest, leading to incremental rather than radical change. The demand for informal mechanisms can be traced to ASEAN states' overriding concern with protecting their internal sovereignty. Any issue that might impinge upon the interests of a member state is sufficient grounds for torpedoing a given proposal.

To summarize, the ASEAN meta-regime developed out of a consensus among elites that there was a need for a regional institution to manage security interactions and preserve national sovereignty in the Cold War environment. This was prompted by the shock of Konfrontasi as well as the realization that British and American troops were withdrawing from Southeast Asia, leaving the region vulnerable to subversion and internecine conflict. By agreeing to strict noninterference in each other's sovereign affairs, the ASEAN member states sought to avoid a repeat of Konfrontasi. The paramount norm of sovereignty was reinforced by procedural norms of decision-making by mutual consultation and consensus, informality and incrementalism, all of which served to maximize member states' freedom to maneuver as they saw fit without interference from their neighbors. In the next sections we examine how this meta-regime, which has undergirded virtually all of ASEAN's initiatives, has also hindered deeper regional integration.

\section{ASEAN'S EVOLVING ECONOMIC COOPERATION}

Although ASEAN's founding documents discussed economic cooperation, it was only in the mid-1970s that it turned actively to promoting this goal. The first scheme, the ASEAN Industrial Projects, sought to foster regionally-based import substitution industrialization, but this effort made little headway (Ravenhill, 1995: 851-52). In 1992, the ASEAN Free Trade Area (AFTA) came into being, soon followed by ASEAN Vision 2020 in Kuala Lumpur in 1997 and the Hanoi 
Plan of Action (HPA) in 1998, which sought to systematically implement the free trade area. In 2003, the Bali Concord II created three 'pillars' of ASEAN cooperation: an ASEAN Security Community (ASC), an ASEAN Socio-Cultural Community (ASCC) and an ASEAN Economic Community. At the Singapore Summit in November 2007, ASEAN leaders signed the Declaration on the AEC Blueprint in the context of a new ASEAN Charter, seeking to establish a single market, a production base, and a fully integrated region by 2015 .

\section{The ASEAN Free Trade Agreement}

With the end of the Cold War, ASEAN confronted the internal question of its own purpose and sought ways to expand its scope beyond security issues. During this time ASEAN members also became increasingly concerned about the growing trend of regionalism in the rest of the world and the flow of foreign investment into China (Elliott and Ikemoto, 2004: 4). Moreover, it feared becoming isolated by the protectionist policies of other regional trade blocs while simultaneously facing pressures from the WTO and the IMF to speed up its own regional trade liberalization (Cuyvers et al., 2005: 3). To this end, the ASEAN states agreed to the creation of AFTA in January 1992.

AFTA can be classified as being relatively weak in strength, liberal in nature and medium in terms of scope. With respect to its nature, members sought to bring all intra-ASEAN tariff levels for non-sensitive goods down to the 0-5\% range within 10 years from 1994. Members instituted a common effective preferential tariff (CEPT) that would make intra-ASEAN exports less expensive and bolster integration. Yet in keeping with an elite-led model, the regime appears to have been created with relatively little private sector input except with regard to the

exclusion of sectors and products (Ravenhill, 1995: 864). The agreement called for different 
categories of liberalization with different target dates. In addition, it called for a ban on quantitative restrictions (such as quotas) on CEPT products and the complete removal of nontariff barriers within 5 years of CEPT concessions.

The regime remained weak in three notable areas. First, Article 6 of the AFTA agreement allowed governments to make exceptions to the CEPT scheme and suspend the provisions if increased imports threatened 'serious injury’ to domestic producers, without clearly explaining what constituted appropriate usage of such exceptions. And second, although a ministerial-level AFTA council was created to supervise CEPT implementation, the Secretariat played a minor role. In keeping with ASEAN norms of incrementalism, the AFTA agreement did not provide a specific timetable for tariff reduction, stating only that tariffs above $20 \%$ should be reduced to 20\% within 5-8 years (later amended to 5 years from 1993), and then reduced again within 7 years (also amended to 5 years from 1993), while tariffs already below $20 \%$ were to be reduced at a schedule to be determined by the members.

The 1995 ASEAN Framework Agreement on Services (AFAS) widened AFTA by focusing on trade in services. The AFAS was envisioned to be a 'GATS-plus' regime in which liberalization would exceed the standards set by the WTO General Agreement on Trade in Services (GATS). A cursory examination of the AFAS liberalization schedules reveals that the member states varied significantly in their levels of industry protection (Findlay, 2005: 186-87). Moreover, the regime remained weak, with liberalization proceeding at a pace comfortable to all members, rather than binding them to a set timetable. In September 1995, the ASEAN economic ministers agreed to create a dispute settlement mechanism, which was largely based on the WTO Dispute Settlement Understanding although it lacked much of its power (Koesrianti, 2005: 238). While certainly a step toward stronger rule-based institutionalization, the original Protocol on 
Dispute Settlement Mechanism was vaguely worded and relied on the potentially politicized AEM to settle appeals. This essentially voluntary mechanism also reflects ASEAN's noninterference norms and the general weakness of the regime.

The impact of the AFTA regime on national actions and interactions was mixed. Taking into account the target dates for tariff reductions (and hence our use of 2000 data), it is worth noting that average tariffs among ASEAN members fell from $12.76 \%$ in 1993 to $4.43 \%$ in 2000 (Garrucho, 2002). In terms of the impact on trade, ASEAN intra-regional trade increased from 21\% in 1993 to $25 \%$ in 1997 , at the onset of the Asian financial crisis. Still, many products that were to be liberalized remained on exclusion lists and little progress took place with respect to service sector trade liberalization or the removal of non-tariff barriers. In short, while AFTA had some important effects, the lack of procedures in key sectors undermined its potentially greater impact.

\section{ASEAN Vision 2020 (1997) and the Hanoi Plan of Action (1998)}

The 1997 Asian financial crisis, in which ASEAN's member states ignored regional coordination in favor of unilateral actions, represented one of the most serious regional shocks that ASEAN faced and stimulated debate over the norm of non-interference. In December 1997, the ASEAN states adopted ASEAN Vision 2020 that declared their intent to proceed with regional integration and liberalize trade in goods, services, investments and capital. This, in turn, led to the 1998 adoption of the Hanoi Plan of Action as a six-year implementation program for ASEAN Vision 2020.

Among the HPA's objectives were the liberalization and strengthening of the financial sector. It also sought to build up industrial cooperation, implement the Framework Agreement on 
the ASEAN Investment Area, encourage sustainable development and private sector involvement, and promote small and medium enterprises. The HPA was considerably more specific than AFTA and accelerated the trade liberalization timeframe for the original six ASEAN members to 2002. In terms of our coding, the regime became somewhat stronger (still lacking a serious dispute settlement mechanism), maintained its overall liberal nature, and expanded further in issue scope.

Under the HPA, ASEAN-6 average tariff levels continued to fall to $1.87 \%$ by 2003 but intra-regional trade remained constant at about $22 \%$ of total trade after 1998 . Observers noted that by early 2005 , only $80 \%$ of the products traded in the ASEAN region were covered by the CEPT Inclusion List, with the other 20\% falling under a variety of exceptions (Cuyvers et al., 2005:58). However, since Most Favored Nation (MFN) rates under the WTO are in general only slightly higher than most of the CEPT rates, and since obtaining MFN certification carries far lower administrative costs, many firms have reportedly just paid MFN rates. Some estimates put the percentage of intra-ASEAN trade actually utilizing AFTA-CEPT rates as low as 5\% (Reyes, 2004).

One positive interpretation of this low differential in tariff rates is that AFTA has fulfilled the ASEAN objective of creating 'open regionalism' to a much larger extent than APEC. With relatively low tariffs, ASEAN can indeed be seen as a logical location for multinationals seeking to develop production networks with an external export focus. At the same time, however, the relatively low level of intraregional trade in ASEAN suggests that the issue scope of AFTA may be too narrow since most of the 'actions' (in this case, tariffs) covered by AFTA are already constrained by a higher-level regime (the WTO), while more damaging 'actions' (e.g., sectoral protection for rice) fall under exception clauses and are thereby allowed to continue. 


\section{From the ASEAN Economic Community to the ASEAN Charter}

Faced with growing concern about the economic rise of China and India, and the new turn to bilateral preferential trade agreements at the turn of the millennium, ASEAN members attempted to accelerate their integration (Ravenhill, 2008). These factors combined with the unsettled security environment marked by the Bali bombing of October 2002 to generate a strong impetus for deeper integration (Smith, 2004: 423). Drawing on a McKinsey and Company report commissioned in May 2002 that sharply criticized ASEAN's prior integration efforts (Schwartz and Villinger, 2004), ASEAN established the AEC with the 2003 Bali Concord II to create a single market and production base for ASEAN with free movement of goods, services, investment, and skilled labor by the year $2020 .^{3}$

The Vientiane Action Program (VAP) of November 2004 laid out plans for further liberalization in goods and services in eleven sectors. Under fast-track liberalization, ASEAN-6 states were to remove the CEPT for these sectors by January 1, 2007 (Cambodia, Laos, Burma and Vietnam have until January 1, 2012 to implement the liberalization measures). For those sectors not slated for fast-track liberalization, the VAP stipulates removal of all tariffs by 2010 (2015 for ASEAN-4 countries) and the establishment of protocols for removing non-tariff barriers. In terms of strength, the various framework agreements for sectoral integration are moderate to weak insofar as there are limited options for enforcing compliance by member states. The nature of the regime for trade in goods is liberal, while its scope is broad, encompassing all sectors. Despite the apparent weakness of the regime, however, liberalization

\footnotetext{
${ }^{3}$ Owing to space constraints, our focus in this section is primarily on trade, although progress has been made in changing the investment regime as well.
} 
in goods has made substantial progress, with the ASEAN-6 countries having slashed tariffs on all of the goods on the inclusion list to 5 percent or lower as of 2003 (Abbugao, 2005).

Liberalization of trade in services under the VAP has proceeded much more slowly than liberalization of trade in goods. It also explicitly calls for the use of multispeed subregional efforts, including the 'ASEAN minus $\mathrm{X}$ ' formula, which allows for member states—with the consensus of other ASEAN states - to postpone accession to ASEAN agreements, and ' $2+\mathrm{X}$ ' agreements, which allow for 2 or more ASEAN states to establish sub-regional arrangements independent of ASEAN. These approaches potentially weaken ASEAN because there is no monitoring institution, thereby allowing member states to create as many of these sub-regional groupings as they wish. Sub-regional groupings can compensate for differences in economic development by allowing some countries to take the lead in trade liberalization, but there is currently no robust mechanism to guarantee that less developed countries will not be left behind.

Overall, however, there have been efforts to strengthen the economic regime through the 2004 Enhanced Dispute Settlement Mechanism, which creates procedures to handle multiple plaintiffs and interested third parties, as well as for the establishment of an independent appellate body. The new DSM represents a significant improvement over the previous mechanism in its attempt to depoliticize the process and its more consistent rule-based framework. Its structure strongly resembles the WTO’s own mechanism in its progression from consultations to panels to SEOM rulings, appeals and compensation for non-compliance. While ASEAN itself cannot impose any sort of supra-national authority over the disputants, it can provide them with a mutually accepted framework within which member states can apply peer pressure to maintain compliance with trade agreements. 
Additional strengthening of ASEAN came about with the singing of the ASEAN Charter at the 13th ASEAN Summit in Singapore on November 20, 2007 and ratified by all members by October 2008. The ASEAN Charter creates a rule-based entity and calls for the creation of enforceable rules in finance, trade, and the environment, as well as the establishment of a regional human rights body. This agreement endorsed the January 2007 Cebu summit's call for liberalizing services sector in ASEAN by 2015 and accelerating the move to full liberalization through the AEC blueprint from 2015 from 2020. In developing the Charter, the members explicitly looked at the EU structures and approach, with the ASEAN Secretary General noting that 'It is no accident that ASEAN has been looking at the European Union’s rich experience as we map out our own plans for becoming a Community by 2015’ (http://www.aseansec.org/20890.htm).

With these new commitments, has ASEAN fundamentally changed? As with previous efforts, it would appear that the meta-regime remains firmly intact. In terms of strength, the regime remains relatively weak. Governments cannot be punished for violating human rights non-interference remains the key norm, and the importance of respecting state sovereignty has been reiterated. Decision-making will remain based on consultation and consensus, rather than any voting majority. And the ASEAN minus $\mathrm{X}$ formula is recognized, thus diminishing the constraining value of the regime. The liberal nature of ASEAN's economic regime still continues, and the scope has been broadened, in this case as noted, with the creation of a human rights body.

Although it is clearly too early to tell what the impact of the ASEAN Charter will be on further economic integration in ASEAN, one noteworthy trend is ASEAN member states' involvement in two different types of extra-regional trade agreements: ASEAN + X, which are 
established between ASEAN and an extra-regional state, and bilateral agreements with extraregional states. ASEAN + X arrangements have been formed with China in 2002, Japan in 2003, India in 2003, and South Korea in 2005, and there are ongoing negotiations with Australia and New Zealand (ANZCERTA). Yet as the same time, individual members have moved forward on their own, negotiating nearly 60 agreements (Ravenhill, 2008), with Singapore in the lead. Rather than uniting the area economically, this approach emphasizes economic and power asymmetries that may seriously undermine ASEAN's integration efforts. ${ }^{4}$ On the more positive side, ASEAN has been united in pursuing the ASEAN plus 3 process involving China, India, and Korea, as well as the ASEAN plus 6 process or East Asian Summit.

\section{Evaluating ASEAN's Economic Cooperation Efforts}

An examination of the economic cooperation in ASEAN can proceed at several levels. With respect to the impact on interactions and national controls, we have already seen that ASEAN members' tariff levels have declined steadily from the early 1990s to below 5\% (ASEAN, 2009); yet at the same time only $65 \%$ of the products in the Inclusion Lists of the ASEAN-6 had zero tariffs (Ravenhill, 2008) and NTBs continue to hinder trade in the region. To what extent has ASEAN economic integration resulted from institutional factors, as opposed to market factors? Michael Plummer (2006) finds that 'ASEAN as a group has been a statistically-significant determinant of international trade flows, including for ASEAN and EU trade.'

Although ASEAN's efforts look impressive with respect to removal of tariffs, intraregional trade remains low compared to other regions. But in general, the East Asia group of 15 countries has a very high level of intra-regional trade, but no formal trade arrangement amongst

\footnotetext{
${ }^{4}$ On the negotiation of bilateral agreements in the Asia Pacific, see Aggarwal and Urata (2006) and Dent (2006). On ASEAN + agreements, see Lim and Walls (2004).
} 
themselves (Kawai, 2005). Although intra-regional trade has not risen dramatically, ASEAN's export performance has been very strong. One must examine the extent to which ASEAN's integration efforts might have contributed to the success of its extra-regional exports, and also the extent to which ASEAN's industrial production structure would benefit from deeper integration. Unfortunately, assessing this is much more complicated, but the lack of significant ASEAN-wide integrated production by MNCs suggests that intra-ASEAN integration has had little effect on ASEAN's export performance. It is worth noting that half of the FDI from the past ten years has gone to Singapore and also parallels its share of export (about $40 \%$ of total ASEAN exports). ${ }^{5}$ By contrast, the least developed economies of Cambodia, Burma, Lao PDR, and Vietnam received less than $10 \%$ of the total FDI inflows in this period.

Assessing AFTA and the AEC, we conclude that the ASEAN economic regime has consistently become more liberal in nature over time and has clearly widened in scope. Yet at the same time, it has remained relatively weak, although recent efforts such as the ASEAN Charter suggest that ASEAN members have been trying to strengthen it. Using the framework presented in Figure 2, how might we analyze the evolution of ASEAN's regime? In terms of regime supply, it is clear that there is no hegemonic power. No country in ASEAN accounts for more than 32\% of its GDP, and although Indonesia, Malaysia, Thailand, and Singapore account for about $80 \%$ of its total GDP (Ravenhill, 2008), these countries have not managed to develop into a ' $\mathrm{k}$ ' group that might collaborate to manage the ASEAN regime. In terms of the nested systems argument, although some see China and India as an economic threat, as John Ravenhill (2006) has noted, ASEAN countries have successfully become suppliers for the Chinese assembly machine. Compared to the formation of the European Coal and Steel Community (ECSC), the forerunner to the EU, the causal logic is reversed. In the case of the ECSC, economic

\footnotetext{
${ }^{5}$ Data on exports and FDI can be found in the ASEAN Statistical Yearbooks.
} 
cooperation was seen as a means to decrease the likelihood of conflict among its member states. With the Soviet Union as an external threat, economic cooperation was driven by the 'higherlevel' consideration of the Cold War context. By contrast, in the ASEAN case, economic cooperation followed security cooperation and the two were not as directly linked.

Demand for an economic regime ranks low on several dimensions. As noted, the low differential between external and internal tariffs means that few firms have an incentive to utilize this arrangement. Moreover, the high degree of consistency among AFTA, the AEC and the GATT/WTO, along with the low degree of intra-regional trade among its members, reduces the need to promote economic liberalization through ASEAN as opposed to the GATT/WTO. Finally, in terms of controlling domestic actors, the overall outward orientation reduces government officials' desire to harness a regime to control domestic actors. In terms of controlling international (regional) actors, most ASEAN states have not imposed significant barriers against each other, and thus have little incentive to push for a robust economic regime to dismantle them.

Given these supply and demand factors, the meta-regime in ASEAN's cases looms large. As Section III argued, the norms of respect for sovereignty and noninterference in other countries' domestic affairs that grew out of ASEAN's security origins hinder efforts to develop strong economic cooperation and an effective dispute settlement body. This problem is compounded further by the procedural norms of decision-making by mutual consultation and consensus. The procedural norm of elite-based diplomacy further creates problems for successful economic cooperation, as policymakers rather than business interests have driven economic integration. Indeed, the fear of China and India may be greater among political elites than firms 
who are happily supplying the Chinese and Indian markets. In short, ASEAN's economic cooperation has been a victim of the success of its security meta-regime.

\section{THE ASEAN ANTI-HAZE REGIME}

One of the most conspicuous tests of ASEAN's political will is the severe air pollution caused by the periodic burning of large forested areas in Indonesia and, to a far lesser extent, East Malaysia and Brunei. Between August and October of 1997, the haze problem in ASEAN reached crisis levels as thousands of people were hospitalized for pollution-related ailments (Brauer and Hisham-Hashim, 1998). According to the Canada-based International Development Research Center, the region's total cost for dealing with the haze was conservatively estimated at nearly $\$ 4.5$ billion, more than the costs of the Exxon Valdez oil spill and the Bhopal chemical spill combined (Schweithelm et al., 1999).

As a problem with significant human and economic costs that ignores national borders, the haze demands broad regional coordination for both emergency response and long-term prevention. In other situations, the need for expediency has led ASEAN's member states to adopt bilateral or unilateral policies, but adopting such an approach toward the haze problem risks creating incentives to free-ride as well as policies that work at cross-purposes. Such coordination relies on individual ASEAN states to enforce regional standards at the domestic level, but there is significant variation in domestic actors' willingness and capacity to do so. In this section, we analyze ASEAN's attempts to forge a regional anti-haze regime. Since the historical details of the haze crisis and ASEAN's response have been covered in depth elsewhere, ${ }^{6}$ we will provide a brief outline of events and focus primarily on applying the institutional design model to ASEAN's anti-haze efforts and its decidedly mixed results.

\footnotetext{
${ }^{6}$ See, for instance: Cotton (1999), Jones (2006), and Severino (2006: 107--16).
} 


\section{Pre-1997 Efforts to Control Haze}

Prior to the 1997 crisis, ASEAN had treated haze in the context of broader transboundary pollution rather than as a separate issue. In 1991, widespread forest fires in Indonesian Kalimantan prompted complaints about haze from Singapore and Malaysia. In December of 1992, ASEAN announced the formation of a joint committee to study the haze and set up a meteorological network for early warning ('ASEAN Experts Plan Panel to Deal with Haze Problem’, 1992). Recurrent haze in 1994 and 1995 led to the convening of the Informal ASEAN Ministerial Meeting on the Environment in both years, which led to the declaration that ASEAN constituted ‘one eco-system’ (ASEAN, 1994), an acknowledgment that in principle, environmental problems could not be adequately addressed solely within domestic contexts.

In June 1995, ASEAN produced the ASEAN Cooperation Plan on Transboundary Pollution, which articulated several concrete measures to improve regional cooperation on crossborder pollution. With regard to haze, the plan recommended prohibitions on biomass burning during dry periods, information sharing and joint activities, and investment in alternative uses of biomass (ASEAN, 1995). In keeping with ASEAN's norms of informality, the ASEAN Cooperation Plan on Transboundary Pollution had no legally binding effect on member states. Moreover, although the plan did lay out a number of measures to build capacity, such as improved sharing of meteorological data and joint firefighting training, it did not include any mention of forest conservation as a measure to reduce the haze. ${ }^{7}$ Moreover, it did not specify a

\footnotetext{
${ }^{7}$ In terms of more specific measures to build capacity, the ASEAN states agreed to develop an information-sharing mechanism, expand the role of the ASEAN Specialized Meteorological Center to predict haze patterns, generate reporting and alerting procedures for relevant national agencies, develop a common air quality index and fire danger rating system, share technology and expertise in fire management, establish a mechanism for regional firefighting response, expand the role of the ASEAN Institute of Forest Management to include training of national-level personnel in forest firefighting, and continue to develop national and regional air pollution management capabilities (Cotton, 1999: 343).
} 
timetable for implementation. The ASOEN was tasked with monitoring implementation and at its September 1995 meeting it established a Haze Technical Task Force (HTTF) that was intended to improve coordination through better haze and fire monitoring mechanisms and the dissemination of relevant meteorological data, including the establishment of a haze alert and monitoring system and the designation of times and places most at risk for fires (ASEAN, 1995).

Returning to the theoretical model of regime development in Figure 2, we can see that the initial demand for a transboundary pollution regime arose from the ASEAN states' realization that a specific agreement could reduce the costs of coordinating regional monitoring, prevention and emergency response efforts. The scope of the resulting arrangement was fairly broad in proposing a range of prevention, education and capacity-building initiatives, with certain notable omissions in areas where fire prevention might directly interfere with economic development, such as in forest conservation. Yet the low perception of threat from haze and forest fires generated no demand to break with ASEAN norms of informality, non-interference and consensus, meaning that the regime's provisions were non-binding and weak. As a result, we would expect the regime to have a limited impact on national actions. This, in fact, is what happened as the impact of the 1997 forest fires and haze far exceeded that of previous environmental disasters.

\section{The 1997 Haze Crisis and the Regional Haze Action Plan}

The fires and resultant haze that engulfed Southeast Asia in 1997 can be traced to two principal causes. First, subsistence and semi-subsistence farmers burned forested areas to clear land for agricultural use, but there is general agreement that the vast majority of fires were started by corporate interests in Indonesia-including several joint ventures with Malaysian businesses—to 
clear land for lucrative timber and palm oil plantations. ${ }^{8}$ In 2006, Indonesia and Malaysia accounted for 87 percent of world palm oil production, and by the end of 2007, Indonesia had overtaken Malaysia in production, going from approximately 5 million metric tons in 1997 to 18.3 million metric tons in 2007-08 (U.S. Department of Agriculture, 2007), with demand being increasingly driven by biofuels. Likewise, the timber industry plays a vital role in the Indonesian economy, comprising 7 percent of GDP in 1997, and in the 1990s exports of Indonesian hardwood plywood accounted for some 70 percent of world market share. (Poffenberger, 1997: 454; Barr, 1998: 2).

Much of the blame for the 1997 haze crisis fell on Indonesia, not only because of the sheer magnitude of the fires there but also because of the Suharto regime's extensive patronclient relationships with the forestry industry through the use of generous tax and investment incentives to logging companies and plantation owners. Suharto and his family also owned shares in timber companies and helped ensure the creation of a plywood cartel—Apkindo—that was overseen by Suharto’s close associate Mohammad ‘Bob’ Hassan, who became his trade minister in 1998 (Barr, 1998). The cozy relations between the government and the timber industry created a serious conflict of interest and incentives for the government to turn a blind eye to environmentally dangerous but economically lucrative burning.

A lack of incentives to prevent rapid clearing of forest meant that concessionaires typically elected to use cheap slash-and-burn clearance, all of which ultimately resulted in massive forest fires and haze. These wasteful practices were abetted by the insufficient capacity of the Indonesian government to enforce forestry regulations and monitor illegal logging. When cases against violators were brought to court, the defendants usually won due to a combination of

\footnotetext{
${ }^{8}$ For instance, Indonesian Environment Minister Sarwono Kusumaatmadja suggested that land clearing on behalf of corporate interests accounted for perhaps 80 percent of all the fires on Sumatra and Kalimantan during the 1997 haze crisis. See Jones (2006: 433-34) and Schewithelm et al. (1999: 135-36). .
} 
corruption, and judiciary officials’ unfamiliarity with new environmental laws. Also, under Indonesian law, the prosecution bears a very heavy burden of proof to demonstrate intent to burn, requiring witnesses or evidence of directives to burn in addition to physical evidence (Meyer, 2006: 213). This is in contrast to Malaysian law, which places the burden of proof on the defendant to refute evidence indicating that fires began on the defendant's property.

While Indonesia’s neighbors and a broad coalition of extra-regional donors contributed resources to support its beleaguered firefighting resources-Malaysia sent over 1,200 firefighters in September and October, Singapore contributed satellite photography, and Australia contributed $\$ 2$ million in aid as well as water bombing equipment-these were all conducted on a bilateral basis. In light of the severity of the crisis, it is remarkable that ASOEN did not convene until September and the joint communiqué scarcely mentioned the haze except for a single sentence expressing ‘appreciation’ for the Haze Technical Task Force (ASEAN, 1997a). It was not until late December 1997, well after the monsoon rains had washed out the haze from the atmosphere, that ASEAN convened its first-ever ministerial meeting on haze and adopted a Regional Haze Action Plan (RHAP).

As in the pre-1997 anti-haze regimes, RHAP laid out a series of capacity-building measures to tackle the haze at a regional level. These were divided into preventive measures, regional monitoring mechanisms, and firefighting capabilities. Unlike the 1995 Cooperation Plan on Transboundary Pollution, though, RHAP set a deadline for member states to develop national-level plans for haze prevention by March 1998. These national plans were to include restrictions on slash-and-burn practices during the dry season, efforts to safely dispose of combustible waste and plans for rapid firefighting response. At a regional level, RHAP pledged to further strengthen regional early warning and monitoring systems and develop procedures for 
rapid regional mobilization of firefighting efforts (ASEAN 1997a). Nevertheless, national governments would still wield primary responsibility for implementation, and since implementation and enforcement were domestic issues, ASEAN could not openly single out a country for criticism of lax enforcement without violating its own norms of non-interference in sovereign affairs. Instead, it obliquely referenced lax enforcement regimes by acknowledging that 'while some member countries have already developed their national policies and strategies, others are in the process of advancing them based on their own development needs, priorities and concerns’ (ASEAN 1997b).

Between December 1997 and August 1999, ASEAN convened a total of nine ministerial meetings on haze. These meetings produced a number of concrete results, including the development of a regional 'zero-burning' policy that would be implemented at the national level, the construction of firebreaks and joint surveillance for early fire detection. But since RHAP's effectiveness hinged on member states' enforcement of laws against slash-and-burn land clearance practices, there was little actual change. During the Eighth ASEAN Ministerial Meeting on Haze on 26 August 1999, barely four months after the adoption of the zero-burning policy, fires erupted in Indonesia and Malaysia. The joint press statement appeared to express some signs of impatience toward Indonesia, although it refrained from outright criticism. ${ }^{9}$ In an interview with the BBC, Simon Tay, the chair of the Singapore Institute for International Affairs and a member of the ASEAN Institute of Strategic and International Studies, stated that ASEAN would not place heavy pressure on Indonesia because of the latter's powerful regional role and instead blamed a lack of adequate enforcement capacity rather than unwillingness on Indonesia's

\footnotetext{
${ }^{9}$ The Ministers expressed their deep concern that despite numerous Ministerial meetings and attention on the regional haze problem, fires have recently recurred in Sumatra, Borneo and some parts of Peninsula Malaysia, and only after a brief dry spell. ... The Ministers urged Indonesia to quickly implement the necessary by-laws and regulations to enforce the zero-burning policy. (ASEAN, 1999).
} 
part. 'I think that even if the Indonesian government in Jakarta had the goodwill to try and do something about [the forest fires and haze], it's very difficult for them because after years of corrupt and weak capacity at the local level, there is a limit to how far they can effectively enforce their own laws' (Tay, 2000).

\section{The 2002 ASEAN Agreement on Transboundary Haze Pollution}

Despite the efforts of ASEAN to curb slash-and-burn practices, the haze persisted and returned each summer. In June 2002, at the World Conference on Land and Forest Fire Hazards in Kuala Lumpur, all ten ASEAN states signed the ASEAN Agreement on Transboundary Haze Pollution. Unlike RHAP, the ASEAN Agreement on Transboundary Haze Pollution would enter into force as a legally binding treaty upon the ratification of six member states. The ASEAN states' willingness to bind themselves to a regional treaty marked a departure from their aversion to formal legal obligations. The Agreement required parties to take immediate steps to control fires and haze in their territories and to implement national legislation required to execute it. It also established an ASEAN Coordinating Center for Transboundary Haze Pollution Control that would facilitate regional anti-haze efforts and resource distribution and serve as a central focal point for emergency response efforts, as well as an ASEAN Transboundary Haze Pollution Control Fund that would provide moneyfor the implementation of the Agreement, though contributions to the Fund would be made on a purely voluntary basis.

A closer look at the Agreement, however, reveals the same weaknesses that rendered RHAP and the ASEAN Cooperation Plan on Transboundary Pollution ineffective in resolving the haze crisis. Its most conspicuous shortcoming is the lack of any enforcement provision such as sanctions for noncompliance. Another problem is the vagueness of signatories' obligations. For example, Article 9 commits parties to develop and implement 'legislative and other 
regulatory measures, as well as programs and strategies to promote zero burning policy to deal with land and/or forest fires resulting in transboundary haze pollution' and to develop 'other appropriate policies to curb activities that may lead to land and/or forest fires.' (ASEAN, 2002). What constitutes an appropriate policy is not explicitly stated. Indeed, without specific standards of expected behavior, the Agreement it is impossible to enforce. While a protocol would help to specify the procedures needed to coordinate regional efforts, none has been put forth yet, even though Article 21 explicitly directs signatories to draw up protocols 'prescribing agreed measures, procedures and standards for the implementation of this Agreement.' (ASEAN, 2002). Alan Tan (2005) notes 'where the surrounding political context is defined less by a demand by state parties for legally enforceable commitments, but more an expectation for moral force and action, prospects for compliance and effectiveness... are affected considerably.' The Agreement on Transboundary Haze Pollution's legally binding status amounted to little more than window dressing in the absence of any enforcement mechanism. Moreover, Indonesia did not ratify the Agreement, meaning that it was not bound by its terms. ${ }^{10}$ Since Indonesia was the largest source of haze pollution by a wide margin, this was a significant blow to the Agreement's effectiveness. When asked why Indonesia had not ratified the Agreement, Foreign Ministry spokesman Yuri Thamrin replied, 'There is no delay in the ratification process. We are now in the administrative process to ratify it. Everything is in place. The related ministries are harmonizing the policy' (Ghani, 2005). As of early 2009, Indonesia still had not ratified the Agreement. On the other hand, it did sign a Memorandum of Understanding with Malaysia in June 2008 under which the latter promised approximately $\$ 600,000$ in aid to provide training and

\footnotetext{
${ }^{10}$ The six parties that ratified the Agreement, thereby causing it to take effect 25 November 2003, were Brunei, Malaysia, Myanmar, Singapore, Thailand and Vietnam.
} 
support for Indonesian farmers, early haze warning systems, and rehabilitation of burnt peat soil ('Malaysia-Indonesia Sign Pact’, 2008).

\section{Evaluating ASEAN's Cooperation Efforts to Combat Haze}

Why has ASEAN relied on such weak instruments to address transboundary haze pollution? The answers to this question lie on both the demand and supply sides of the regime creation process. The establishment of new mechanisms, including the regular meetings of the ASEAN Ministerial Meeting on Haze and the Haze Technical Task Force, helped to reduce the potential transaction costs of coordinating prevention and response efforts by increasing transparency and establishing working relationships among relevant officials and agencies. Under the 2002 Agreement, the establishment of an ASEAN Coordinating Center on Transboundary Haze Pollution Control would also help to reduce information costs by consolidating national-level data in a single centralized location, assuming it possessed the necessary resources to carry out its functions.

In terms of controlling domestic and international actors, the anti-haze regime was far less effective, in no small part because of the ASEAN states' need to balance this demand with their desire to comply with broader ASEAN norms of non-interference, decision-making by consensus, and the preservation of national sovereignty. The Regional Haze Action Plan ostensibly sought to lock domestic actors into a commitment to adopt zero-burning policies. Likewise, the Agreement on Transboundary Haze Pollution sought to compel its signatories to implement and enforce legislation against burning. Yet none of these documents provided for enforcement mechanisms, leading to a failure of the regime to significantly affect national actions. This can be attributed in large part to strict adherence to ASEAN norms of informality and non-interference, which in turn can be caused by a member state's unwillingness to 
antagonize domestic interests by enforcing anti-haze legislation, particularly when such interests are tightly bound to a leader's political power base. As a result, enforcement at the ASEAN level through sanctions could place leaders in a position where they would have to choose between damaging relations with other ASEAN states and damaging relations with powerful domestic interests. Such a situation would very much constitute a violation of non-interference.

\section{CONCLUSION}

Despite vigorous institutional efforts, ASEAN has made much more limited progress than one might have anticipated in the liberalization of trade and the control of haze. To more systematically investigate this evolution, we presented an analytical approach to distinguish among various aspects of governance, distinguishing principles and norms (the meta-regime) from the rules and procedures of an arrangement (the regime). We also considered how regimes might influence national actions, both unilateral and bilateral accords, and how these in turn would likely affect international interactions. Yet while meta-regimes influence regimes, and these in turn affect national actions and interactions, we showed how each of these elements is also driven by political and economic causal factors. We discussed how various supply and demand factors can shape international regimes. The former include the presence or absence of a hegemon and the incentives of the hegemon within nested systems. On the demand side, lower transaction costs, the interest of states in controlling international and domestic actors, and the concern for nesting new institutions in existing ones can drive regime formation.

Although the issue areas of trade cooperation and haze control are very different, we have argued that ASEAN's inability to further cooperation has been rooted in its meta-regime of noninterference, sovereignty, incrementalism, informality and consensual decision-making. This 
meta-regime, which first emerged as a result of the Cold War security situation in Southeast Asia, has remained largely unchanged in the 40-plus years since ASEAN's establishment. Even as ASEAN's security situation has changed significantly and ASEAN itself has greatly expanded the range of issues within its purview, it remains committed to a meta-regime that jealously protects sovereignty at the expense of deep multilateral integration. While the meta-regime may have served its members well on some dimensions of handling regional conflict, and while we have also seen demand and supply factors that might have strengthened the trade and anti-haze regimes, the consensus on non-interference nevertheless undermines efforts to address other key issues.

How might ASEAN overcome this hurdle? One possible approach is to change the ASEAN meta-regime directly by altering the norm of non-interference. This would be very difficult for several reasons, but the most important one for our purposes is the fact that the metaregime undergirds not just the trade and anti-haze regimes but all of the other ASEAN regimes, including security, and serves to protect member states against perceived challenges to their sovereignty. This is especially important considering the authoritarian nature of many ASEAN governments and less-than-stable domestic political conditions. These conditions did not change with the end of the Cold War. Rather than altering the norms of non-interference and informality, ASEAN sought to extend them throughout East Asia and help mitigate intra-regional conflict, the most prominent example being the 1993 establishment of the ASEAN Regional Forum, which brings major regional players together for regular informal discussion about security matters (Emmers, 2008: 194--98). The 1997 Asian financial crisis prompted sharp debate within ASEAN over non-interference and resulted in the proposal of 'flexible engagement', which would have allowed member states to criticize each other's domestic policies if such policies 
were damaging to their interests or else had other regional effects. But the ASEAN states overwhelmingly rejected 'flexible engagement' because of its potential for undermining national sovereignty (Haacke, 2005: 189). They did, however, agree to ‘enhanced interaction’, which allows members to comment on one another's domestic policies whenever they have regional effects, but such criticism cannot be framed as originating from within the ASEAN framework (Narine, 2002). 'Enhanced interaction’ has been sorely tested by Burma’s continued detention of pro-democracy activist Aung San Suu Kyi, which has proven to be a major blemish on ASEAN's public image. Some scholars have suggested that 'enhanced interaction' may indicate a softening of non-interference (Katsumata, 2004: 237--54; Hind, 2001; Katanyuu, 2006), but it is notable that the ASEAN governments did not publicly call on Burma to relinquish its 2006 rotating chairmanship of the Association, instead relying on quiet diplomacy and pressure from the United States and the European Union, both of which had threatened to boycott ASEAN meetings (Haacke, 2005: 199--201). Put differently, there has been an effort to nest 'enhanced interaction’ within the existing norm of non-interference, thereby preserving it.

Turning specifically to the economic regime, one approach at this level would be to foster the development of a new economic regime within the existing meta-regime. According to this logic, pressure from businesses and other societal groups would alter the meta-regime by fostering a greater willingness to have stronger constraints on member states. But as we have seen, there is little business pressure to promote intra-regional trade. As Ravenhill (2008: 482) succinctly puts it: ‘...the supply of intra-ASEAN trade liberalization has exceeded the demand from the business community for it.' With respect to one key demand factor - controlling the detrimental effects of domestic protectionism on other member states' economies_ASEAN has been unsuccessful. On this latter point, one cannot help but notice an apparent contradiction 
between ASEAN's allergy to formalized regional institutions on the one hand and their willingness to use the WTO's binding dispute settlement mechanism. If ASEAN states have no problem with the WTO, then why are they so reluctant to establish less formal institutions at the regional level?

A third approach would be to establish a separate meta-regime for economic affairs and decouple it from the security meta-regime. With respect to non-interference, surely one might believe that asking a neighboring country to stop restricting imports is not the same as coercing that country to change its party system. Thus, the notion of noninterference could be reserved for the security meta-regime but not apply to economic affairs.

Fourth and finally, one can be more radical and ask: if ASEAN stopped trying to promote regional economic integration and simply worked within the WTO system or, even a much less desirable option, let member states pursue bilateral trade liberalization, would ASEAN members really be worse off? On this score, we believe the jury is still out.

Turning to the anti-haze regime, we similarly consider four possible scenarios to strengthen it. One option is to do away with an ASEAN-based approach to combating the haze and nest the anti-haze regime within a broader multilateral regime. The problem with this approach is that there is no multi-regional counterpart to the ASEAN Agreement on Transboundary Haze. In other words, if ASEAN were to give up a regional approach to the haze problem, there would be no other mechanism to fill the void except for unilateral and bilateral actions. It is true that there does exist the 1979 Convention on Long-Range Transboundary Air Pollution (LRTAP), which is overseen by the United Nations Economic Commission for Europe (UNECE) and currently has two signatories and 51 parties, including the United States, the Russian Federation, and the members of the European Union. LRTAP, designed to address the 
problem of acid rain, is notable for being a high-compliance regime and for producing eight protocols to reduce emissions to specific targets since its initial signing. But as Brachtl (2005) notes, countries that were not part of the original negotiations would likely be hesitant to accede to a treaty that they were not involved in building. Moreover, nesting the anti-haze regime within a broader multi-regional regime would likely involve the adoption of more formal norms and practices that conflict with the ASEAN meta-regime.

A third possibility is to indirectly change the meta-regime by forming a coalition to strengthen the anti-haze regime, possibly inducing spillover effects. While this is possible in theory, in practice, as we have argued, the meta-regime is the very thing inhibiting change in the anti-haze regime. Such a coalition would only be effective if its members were willing to place coordinated pressure on governments to curb slash-and-burn clearing, causing them to risk angering domestic interest groups. The ASEAN states would likely be extremely circumspect about breaching non-interference because of the potential precedent it would set for interactions in other areas. While the ASEAN states undoubtedly desire the elimination of the haze problem, it is not at all the case that they want to do away with the norm of non-interference altogether, as the example of 'flexible engagement' illustrates.

This leaves a fourth option, which is to establish a separate meta-regime for environmental matters that does not strictly adhere to non-interference, while simultaneously preserving the existing ASEAN meta-regime for security matters. This would allow for greater formality and more stringent enforcement in environmental cooperation. One significant problem would be determining issue scope-where environmental matters end and fundamental matters of sovereignty and political stability begin, as the latter would fall within the purview of the noninterference norm. One could argue, for instance, that how the Indonesian government handles 
its concessions to palm oil interests is fundamentally a sovereign matter even though the result is often open burning, which is clearly an environmental issue with regional externalities. Without a clear delineation between what is and is not covered by the separate environmental metaregime, the ASEAN states would remain extremely concerned that the relaxation of noninterference in environmental issues would spill over into other areas. Nevertheless, if ASEAN is committed to addressing transboundary haze pollution as a body, this option suggests that it may not need to do away with the sacrosanct norm of non-interference. 


\section{BIBLIOGRAPHY}

Abbugao, M. (2005) 'ASEAN on track to achieve zero-tariff goals, but challenges remain', Agence France Presse, July 20.

Acharya, A. (2001) Constructing a Security Community in Southeast Asia: ASEAN and the Problem of Regional Order. London: Routledge.

Acharya, A. (2003) 'Regional Institutions and Asian Security Order: Norms, Power, and Prospects for Peaceful Change', in M. Alagappa (ed) Asian Security Order: Instrumental and Normative Features, Stanford: Stanford University Press, pp. 210--236.

Aggarwal, Vinod K. (1985) Liberal Protectionism. Berkeley: University of California Press.

Aggarwal, Vinod K. ed. (1998) Institutional Designs for a Complex World. Ithaca: Cornell University Press.

Aggarwal, Vinod K. (1994) 'Comparing Regional Cooperation Efforts in the Asia-Pacific and North America', in Andrew Mack and John Ravenhill ( eds) Pacific Cooperation: Building Economic and Security Regimes in the Asia Pacific Region, Sydney: Allen and Unwin, pp. 40--65.

Aggarwal, Vinod K. and Shujiro Urata, eds. (2006) Bilateral Trade Arrangements in the AsiaPacific: Origins, Evolution, and Implications. New York: Routledge.

Ahmad, R. (2002) ‘ASEAN Inks Landmark Deal to Battle Haze’, Straits Times, June 11.

Andaya, B. W. and Leonard Y. A. (2001) A History of Malaysia. 2nd ed. Honolulu: University of Hawai'i Press.

ASEAN (1971) Joint Communiqué of the Fourth ASEAN Ministerial Meeting. March 12--13. $<$ http://www.aseansec.org/1234.htm>.

ASEAN (1994) Joint Press Statement of the Informal ASEAN Ministerial Meeting on the Environment. October 21. <http://www.aseansec.org/9023.htm>

ASEAN (1995) ASEAN Cooperation Plan on Transboundary Pollution. $\leq$ http://www.aseansec.org/9803.htm>.

ASEAN (1997a) Joint Press Release of the Eighth Meeting of The ASEAN Senior Officials on The Environment. September 8-10. <http://www.aseansec.org/9014.htm>.

ASEAN (1997b) Regional Haze Action Plan. December 23. $<$ http://www.aseansec.org/9059.htm>.

ASEAN (1999) Joint Press Release of the Eighth ASEAN Ministerial Meeting on Haze. August 26. <http://www.aseansec.org/1684.htm>.

ASEAN (2002) ASEAN Agreement on Transboundary Haze Pollution. June 10. $<$ http://www.aseansec.org/images/agr_haze.pdf >

ASEAN (2009) Overview: Association of Southeast Asian Nations. $<$ http://www.aseansec.org/64.htm>.

'ASEAN Experts Plan Panel to Deal with Haze Problem' (1992) Straits Times, December 22.

Barr, C. (1998) 'Bob Hasan, the Rise of Apkindo, and the Shifting Dynamics of Control in Indonesia’s Timber Industry’, Indonesia, 65: 1--36.

Brachtl, M. (2005) 'Capitalizing on the Success of the LRTAP Regime to Address Global Transboundary Air Pollution', in L. Suskind and W. Moomaw (eds) Papers on International Environmental Negotiation, Cambridge: PON Books.

Brauer, M. and Hisham-Hashim, J. (1998) 'Fires in Indonesia: Crisis and Reaction', Environmental Science and Technology, 32(17): 404A--07A.

Can the European Union be a Model for Asia?',Talk by the Secretary General of ASEAN 
at the Konrad Adenauer Foundation Berlin, 16 July 2007.

http://www.aseansec.org/20890.htm).

Chia, S. Y. (2004) 'Economic cooperation and integration in East Asia’, Asia-Pacific Review, 11(1): 1--19.

Chow, Jonathan T. (2003) “After the Sweetness”: Assessing Norm Adherence and Identity Formation in ASEAN Security Cooperation, unpublished thesis, Williams College.

Coase, R. H. (1960) 'The Problem of Social Cost', Journal of Law and Economics 3: 1--44.

Cotton, J. (1999) 'The 'Haze' over Southeast Asia: Challenging the Asean Mode of Regional Engagement', Pacific Affairs 72(3): 331--51.

Curzon, G. (1966) Multilateral Commercial Diplomacy. New York: Praeger.

Cuvyers, L., Philippe D. L. and Verherstraeten, S. (2005) 'From AFTA towards an ASEAN economic community and beyond', CAS Discussion Paper 46, Antwerp.

Cuyvers, L. and Pupphavesa W. (1996) 'From ASEAN to AFTA', CAS Discussion Paper 6, Antwerp.

Dent, C. (2006) 'The New Economic Bilateralism in Southeast Asia: Region Convergent or Region Divergent?’ International Relations of the Asia-Pacific, 6(1): 81--111.

Elliott, R. J. R. and Ikemoto K. (2004) 'AFTA and the Asian Crisis: Help or Hindrance to ASEAN Intra-Regional Trade?', Asian Economic Journal 18(1): 1--23.

Emmers, R. (2008) 'Southeast Asia's New Security Institutions', in V.K. Aggarwal and M.G. Koo (eds) Asia's New Institutional Architecture: Evolving Structures for Managing Trade, Financial, and Security Relations, Berlin: Springer Verlag, pp. 181--214.

Findlay, C. (2005) 'Services Trade Liberalization in ASEAN', in D. Hew (ed) Roadmap to an ASEAN Economic Community, Singapore: Institute of Southeast Asian Studies, pp. 172$-95$.

Finlayson, J. and Zacher, M. (1981) 'The GATT and the Regulation of Trade Barriers: Regime Dynamics and Effects', International Organization, 35(4): 561--602. 'Framework Agreement on Enhancing Asean Economic Cooperation', Singapore: ASEAN, 1992.

Garrucho, P. (2002) 'A Look Back at a Decade of AFTA.' $<$ http://www.aseansec.org/peter_garrucho.htm>.

Ghani, A. (2005) 'Testing Times for ASEAN Haze Pact; Indonesia Has Yet to Ratify Landmark Agreement Signed Two Years Ago', Straits Times, August 12.

Haacke, J. (2003a) ASEAN's Diplomatic and Security Culture: Origins, Development and Prospects. London: RoutledgeCurzon.

Haacke, J. (2003b) ‘ASEAN’s Diplomatic and Security Culture: a Constructivist Assessment’, International Relations of the Asia-Pacific 3: 57--87.

Haacke, J. (2005) “'Enhanced Interaction’ with Myanmar and the Project of a Security Community: Is Asean Refining or Breaking with Its Diplomatic and Security Culture?', Contemporary Southeast Asia 27(2): 188--216.

Haas, E.B. (1980) 'Why Collaborate? Issue-linkage and international regimes', World Politics, 32(3): 357--405.

Hammergren, L. (1998) 'Political Will, Constituency Building, and Public Support in Rule of Law Programs', United States Agency for International Development, Center for Democracy and Governance, PN-ACD-023.

Hew, D. and Soesastro H. (2003) 'Realizing the ASEAN Economic Community by 2020', ASEAN Economic Bulletin, 20(3): 292--96. 
Hund, M. (2001) 'The Development of ASEAN Norms Between 1997 and 2000: A Paradigm Shift?', ZOPS Occasional Paper No. 15., University of Trier.

'Jakarta Has Done 'Too Little, Too Late’' (1997) Straits Times, September 24.

Jones, D. S. (2006) 'ASEAN and Transboundary Haze Pollution in Southeast Asia', Asia Europe Journal 4: 431--46.

Jones, D. M. and Smith, M. L.R. (2007) 'Making Process, Not Progress: ASEAN and the Evolving East Asian Regional Order’, International Security 32(1): 148--84.

Katanyuu, R. (2006) 'Beyond Non-Interference in ASEAN: The Association's Role in Myanmar’s National Reconciliation and Democratization’, Asian Survey 46(6): 825--45.

Katsumata, H. (2004) 'Why Is ASEAN Diplomacy Changing? From 'Non-Interference' to 'Open and Frank Discussions’', Asian Survey 44(2): 237--54.

Kawai, M. (2005) 'Chapter 8: Regional Economic Integration and Co-operation in East Asia', Policy Coherence Towards East Asia: Development Challenges for OECD Countries, Paris: OECD Publishing.

Keohane, R. O. (1984) After Hegemony: Cooperation and Discord in the World Political Economy, Princeton: Princeton University Press.

Koesranti (2005) The Development of the ASEAN Trade Dispute Settlement Mechanism: From Diplomacy To Legalism, unpublished PhD these, Faculty of Law, University of New South Wales.

Krasner, S. D. (1982) 'Structural Causes and Regime Consequences: Regimes as Intervening Variables’, International Organization 36(2): 185--205.

Lay, H. T. (2004) 'Will ASEAN Economic Integration Progress Beyond a Free Trade Area?’, International and Comparative Law Journal 53: 935--67.

Leifer, M. (1989) ASEAN and the Security of South-East Asia, London: Routledge.

Lim, H. and Walls M. (2004) 'ASEAN after AFTA: What's Next?', Dialogue and Cooperation 3: 91--103.

Lloyd, P. and Smith P. (2004) 'Global Economic Challenges to ASEAN Integration and Competitiveness: A Prospective Look', Final Report to ASEAN, September.

Mackie, J. A. C. (1974) Konfrontasi: The Indonesia-Malaysia Dispute, 1963-1966, New York: Oxford University Press.

'Malaysia-Indonesia Sign Pact for Better Cooperation to Fight Haze,' (2008) Asia Pulse. June 6.

Meyer, J. (2006) ‘Transboundary Perspectives on Managing Indonesia’s Fires,' Journal of Environment Development 15: 202--223.

Narine, S. (2002) Explaining ASEAN: Regionalism in Southeast Asia, Boulder, Colo.: Lynne Rienner Publishers.

Nesadurai, H. (2003) 'Governing the Asia Pacific: Beyond the 'New Regionalism'”, Third World Quarterly, 24(2): 235--53.

Ong, K. Y. (2005) 'Political Will is Key to Success of ASEAN Economic Integration', ASEANONE, April.

Plummer, M. (2006) 'The ASEAN Economic Community and the European Experience’, paper presented at the ASSA Meetings, January.

Poffenberger, M. (1997) 'Rethinking Indonesian Forest Policy: Beyond the Timber Barons', Asian Survey, 37(5): 453--69.

Ramcharan, R. (2000) 'ASEAN and Non-Interference: A Principle Maintained', Contemporary Southeast Asia, 22(1): 60--88. 
Ravenhill, J. (1995) 'Economic Cooperation in Southeast Asia: Changing Incentives', Asian Survey, 35(9): 850--66.

Ravenhill, J. (2006) 'The Political Economy of the New Asia-Pacific Bilateralism: Benign, Banal or Simply Bad?', in V. K. Aggarwal and S. Urata (eds) Bilateral Trade Arrangements in the Asia-Pacific: Origins, Evolution, and Implications, New York: Routledge, pp. 27--49.

Ravenhill, J. (2008) 'Fighting Irrelevance: An Economic Community with ASEAN Characteristics', Pacific Review, 21(4): 469--88.

Reyes, R. A. (2004) 'The ASEAN Model of Economic Integration', The Jakarta Post, July 19.

Reyes, R., n.d. 'Will ASEAN Economic Integration help the Poor?', $<$ http://www.aseansec.org/16508/htm>.

Schwartz, A. and Villinger R. (2004) ‘Integrating Southeast Asia’s Economies’, McKinsey Quarterly, February.

<http://www.mckinseyquarterly.com/Integrating_Southeast_Asias_economies_1392/>.

Schweithelm, J., Jessup T. and Glover D. (1999) 'Chapter 6: Conclusions and Policy Recommendations' in D. Glover and T. Jessup (eds) Indonesia's Fires and Haze: The Cost of Catastrophe, Ottawa: International Development Research Center, pp. 130--44.

Severino, R. (2006) Southeast Asia in Search of an ASEAN Community: Insights from the Former ASEAN Secretary-General, Singapore: Institute of Southeast Asian Studies.

'Singapore Says Fire Deliberate' (1997) Hobart Mercury, October 2.

Smith, A. (2004) ‘ASEAN’s Ninth Summit: Solidifying Regional Cohesion, Advancing External Linkages', Contemporary Southeast Asia, 26(3): 416--33.

Snidal, D. (1985) 'The Limits of Hegemonic Stability Theory', International Organization, 39(4): 579--614.

Soesastro, H. (2003) 'An ASEAN Economic Community and ASEAN +3: How Do They Fit Together?’, Trade Working Papers 432, East Asian Bureau of Economic Research, revised.

'Sony 'Powerless' to Cope with Forest Fires' (2000) Jakarta Post, July 31.

'Suharto Apologizes to ASEAN Neighbors for Forest Fires' (1997) Deutsche Presse-Agentur, September 16.

Tan, A. K-J. (2005) 'The ASEAN Agreement on Transboundary Haze Pollution: Prospects for Compliance and Effectiveness in Post-Suharto Indonesia', New York University Environmental Law Journal 13(3): 647--722.

Tan, S. (1994) 'Haze Appears Bad, But It’s Not Really Hazardous', Straits Times, October 1.

Tay, S. (2000) 'What Pressure Can Be Put on Jakarta Government', Straits Times, March 10.

United States Department of Agriculture. (2007) 'Indonesia: Palm Oil Production Prospects Continue to Grow', U.S. Department of Agriculture Foreign Agriculture Intelligence Report, December 31. $<$ http://www.pecad.fas.usda.gov/highlights/2007/12/Indonesia_palmoil/>.

'Vientiane Action Program as ASEAN’s Roadmap', ASEAN Summit 2005 Backgrounder. $<$ http://www.ops.gov.ph/asean2005/backgrounder.htm>.

'What a Mockery of Suharto Apology, Says DAP Leader' (1997) Straits Times, September 30. Yoshimatsu, H. (2006) 'Collective Action Problems and Regional Integration in ASEAN', Contemporary Southeast Asia, 28(1):115--40. 
Figure 1: Governance Structures and their Effect on Interactions

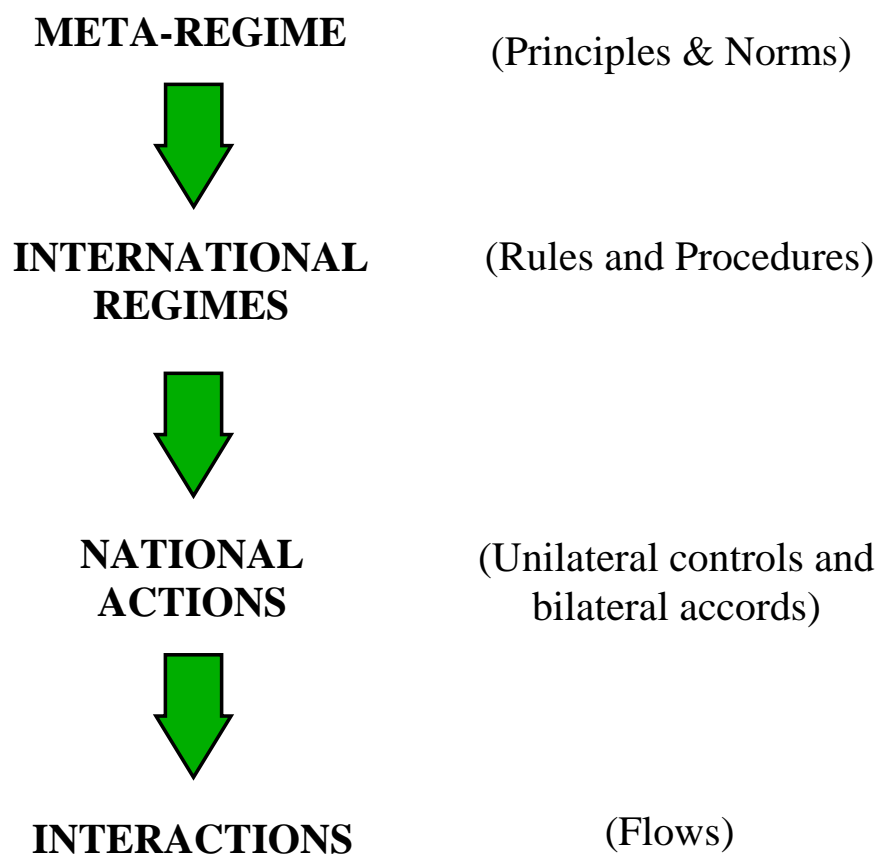

Source: Aggarwal (1985:20). 


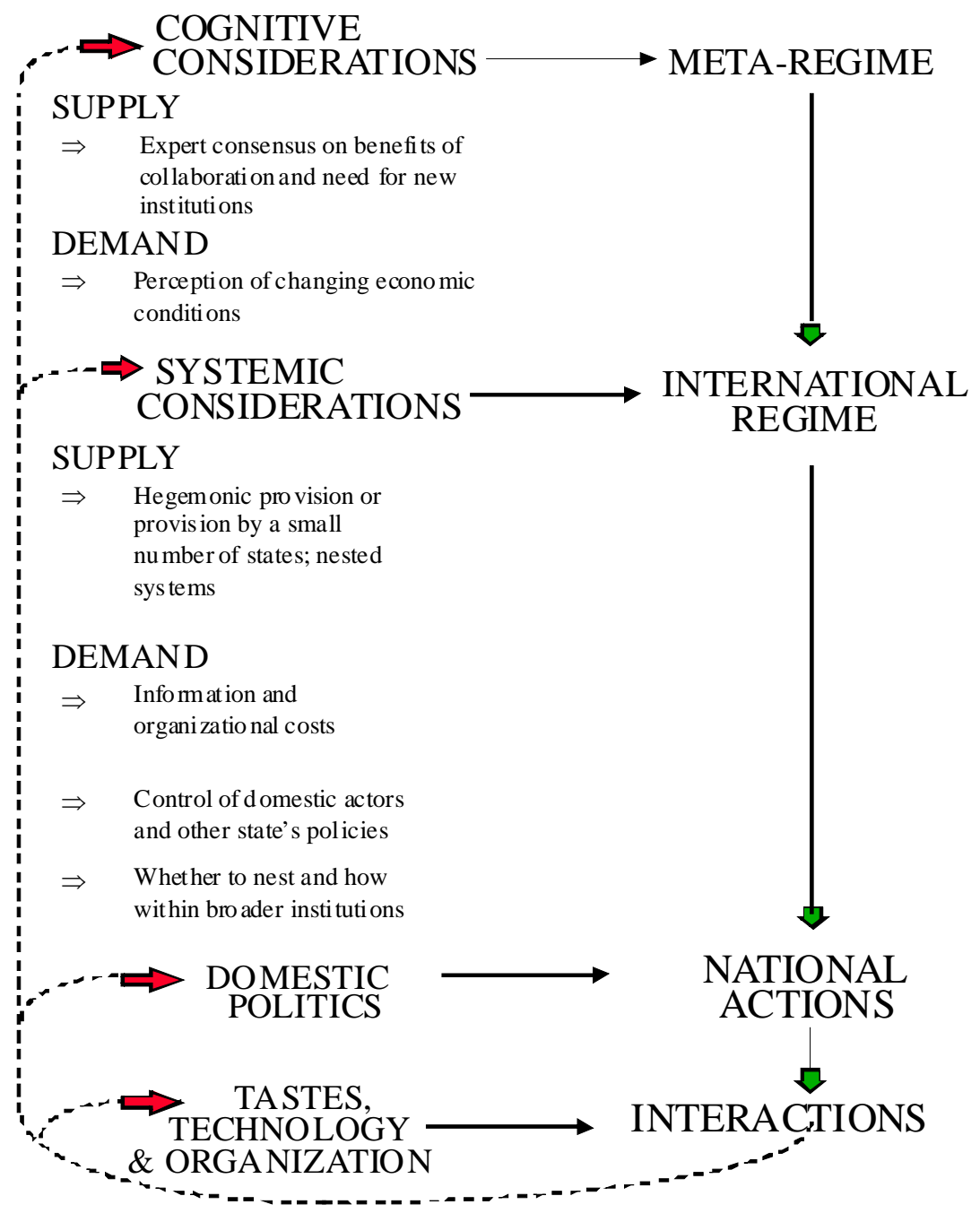

(Principles \& Norms)

(Rules \& Procedures) Strength, Nature \& Scope

(Unilateral Controls and Bilateral Accords)

(Trade and Financial Flows)

Source: Adapted from Aggarwal (1994:46). 